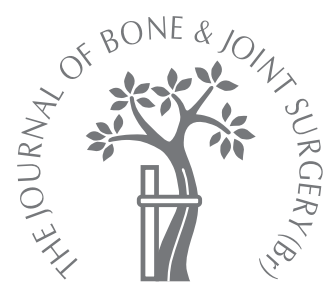

\title{
Revision total hip replacement using the Kerboull acetabular reinforcement device with morsellised or bulk graft
}

\author{
RESULTS AT A MEAN FOLLOW-UP OF 8.7 YEARS
}

K. Kawanabe,

H. Akiyama,

E. Onishi,

T. Nakamura

From the Department

of Orthopaedic

Surgery, Kyoto

University, Kyoto, Japan
K. Kawanabe, MD, PhD,

Associate Professor

H. Akiyama, MD, PhD,

Assistant Professor

E. Onishi, MD, Orthopaedic

Surgeon

T. Nakamura, MD, PhD,

Professor

Department of Orthopaedic

Surgery, Faculty of Medicine

Kyoto University, 54 Kawahara-

cho, Shogoin, Sakyo-ku, Kyoto,

606-8507, Japan.

Correspondence should be sent to Dr K. Kawanabe; e-mail:

kkeiichi@kuhp.kyoto-u.ac.jp

(C)2007 British Editorial Society of Bone and Joint Surgery doi:10.1302/0301-620X.89B1. $18037 \$ 2.00$

$J$ Bone Joint Surg [Br] 2007;89-B:26-31.

Received 20 April 2006;

Accepted after revision 12

September 2006

\begin{abstract}
We retrospectively evaluated 42 hips which had undergone acetabular reconstruction using the Kerboull acetabular reinforcement device between September 1994 and December 1998. We used autogenous bone chips from the ilium and ceramic particle morsellised grafts, even in large acetabular bone defects, in the early stages of the study. Thereafter, femoral head allograft was used as bulk graft in patients with large acetabular defects.

Ceramic blocks and the patients' contralateral femoral head were also used as bulk graft. The mean follow-up period was 8.7 years (4.3 to 12$)$.

Survivorship analysis was performed using radiological failure of the acetabular component, irrespective of whether it was revised, or not, as the end-point.

The survival rate of the morsellised graft group (25 hips) and the bulk graft group (17 hips) at ten years was $53 \%$ (95\% confidence interval (Cl) $42.5 \%$ to $63.5 \%$ ) and $82 \%(95 \% \mathrm{Cl}$ $\mathbf{7 2 . 4 \%}$ to $91.6 \%$ ), respectively. The mid-term results of revision total hip replacement with the Kerboull device were better when bulk graft was used in any size of bone defect.
\end{abstract}

In the presence of severe bone loss, revision of the acetabular component of a total hip replacement (THR) is challenging since the remaining bone is often thin or eburnated, providing poor anchorage for the bone cement. As a result, early failure is common after revision surgery using conventional cemented acetabular components with rates of failure ranging from $15.8 \%$ at an average follow-up of 3.6 years to $51 \%$ at a maximum follow-up of six months. ${ }^{1-5}$

Several techniques have been described for the repair of these deficiencies, including the use of bone autograft or allograft in conjunction with cemented ${ }^{6-8}$ or cementless components, ${ }^{9}$ augmentation using metal mesh, ${ }^{10}$ or acceptance of a high centre of rotation with cementless components. ${ }^{11}$ In addition, a variety of acetabular reinforcement rings or cages has been used with or without supplementary bone grafts. ${ }^{12-15}$

Since 1994, in revision THR we have used the Kerboull acetabular reinforcement ring with morsellised or bulk grafts fashioned from femoral head allograft, autogenous bone, or artificial bone materials. A previous report on the use of this device was encouraging, with only three failures in 53 patients at a mean follow-up of eight years. ${ }^{13}$

Our aim was to analyse the mid-term results of revision THR using the Kerboull device and to examine the relationship between the stability of the acetabular component and the type of bone graft used, whether morsellised or in bulk form.

\section{Patients and Methods}

Between September 1994 and December 1998, we retrospectively reviewed 42 patients (46 hips) who had undergone revision THR with cemented acetabular components using the Kerboull acetabular reinforcement device (Howmedica, Herouville, France). All had received either morsellised or bulk allograft. Two patients (two hips) died from unrelated causes, we were unable to trace one patient and one refused to return for follow-up. This study is therefore based on the remaining 38 patients ( 42 hips). There were 36 women and two men with a mean age at the time of revision of 60 years ( 37 to 85 ). The mean followup was 8.7 years ( 4.3 to 12 ).

The initial diagnoses were osteoarthritis secondary to acetabular dysplasia in 37 hips, rheumatoid arthritis in one, osteonecrosis of the femoral head in one, haemophilia in one and gout in two. The revision surgery was undertaken for aseptic loosening in 39 hips and for infection of three. The previous operations included 27 THRs, 11 bipolar arthro- 

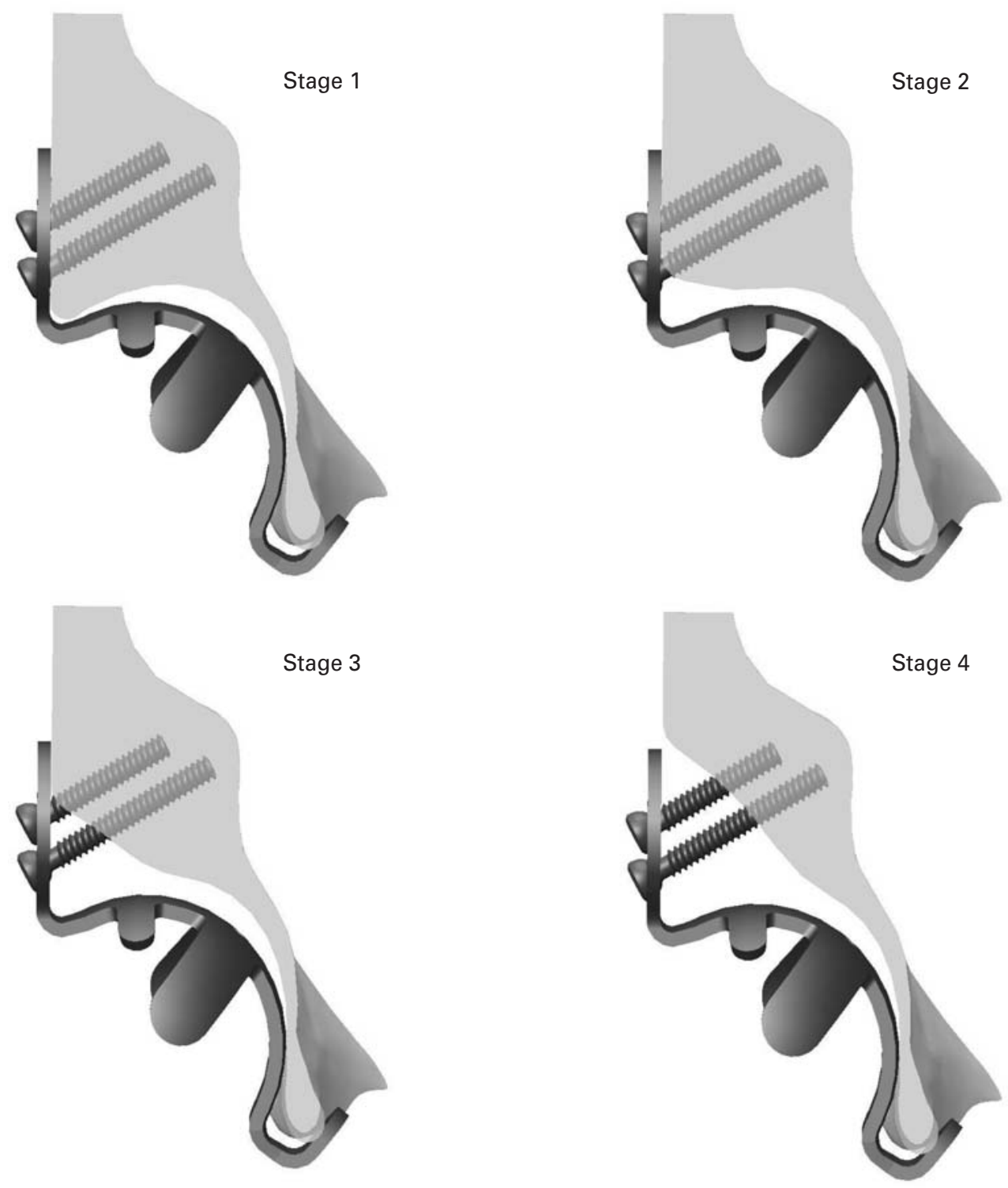

Fig. 1

Diagram showing the stages of superior acetabular bone loss in relation to the placement of the rounded Kerboull device plate.

plasties, and four cemented hip resurfacing arthroplasties. The mean number of previous operations was 1.2 (1 to 3 ).

The acetabular defects had been classified according to the system of grading of the American Academy of Orthopedic Surgeons (Table I). ${ }^{16}$ Type-II defects (cavitary bone loss) were present in 13 hips (31\%), type-III (combined cavitary and segmental bone loss) in 28 hips $(67 \%)$ and type-IV (pelvic discontinuity) in one (2\%). Additional staging (by the author's own system) of the acetabular bone defect was performed according to the severity of the superior segmental bone loss since stability of the acetabular component might have depended on this. In stage 1, there was no superior bone loss and the whole of the rounded plate of the Kerboull reinforcement device could be placed against the host bone. Stage 2 indicated moderate bone loss, with $50 \%$ to $99 \%$ of the rounded plate in contact with the host bone. Stage- 3 patients had extensive bone loss with $1 \%$ to $49 \%$ of the rounded plate touching the host bone. Stage-4 patients had such massive bone loss that no part of the rounded plate could be placed on the host bone (Fig. 1). There were 13 patients with stage- 1 (31\%), 14 with stage$2(33 \%), 12$ with stage-3 (29\%), and three with stage-4 deficiencies $(7 \%)$. All staging had been carried out by a single observer $(\mathrm{KK})$ who reviewed the immediate pre- and post-operative radiographs on two occasions. The mean rate of placement of the plate on host bone was $100 \%$, $63.0 \%(50 \%$ to $90 \%), 36.9 \%(19 \%$ to $48 \%)$ and $0.0 \%$ in stages 1, 2, 3 and 4,respectively. There was a statistical difference between each two groups $(\mathrm{p}<0.01)$. 
Table I. Stability of the acetabular component using the American Academy of Orthopedic Surgeons (AAOS) ${ }^{16}$ classification

\begin{tabular}{|c|c|c|c|c|c|}
\hline \multirow{2}{*}{$\begin{array}{l}\text { AAOS } \\
\text { classification }\end{array}$} & \multicolumn{2}{|c|}{ Morsellised graft } & \multicolumn{2}{|c|}{ Bulk graft } & \multirow[b]{2}{*}{ Total } \\
\hline & Stable & Failure & Stable & Failure & \\
\hline II & 10 & 2 & 1 & 0 & 13 \\
\hline III & 4 & 9 & 12 & 3 & 28 \\
\hline IV & 0 & 0 & 1 & 0 & 1 \\
\hline Total & 14 & 11 & 14 & 3 & 42 \\
\hline
\end{tabular}

Either morsellised or bulk bone allograft was used in all hips. In 25 hips $(60 \%)$ morsellised grafts consisted of autogenous bone chips from the ilium mixed in a ratio of 50:50 with artificial bone consisting of A-W glass ceramic ${ }^{17}$ with a diameter of $4 \mathrm{~mm}$ and cylinder length of $40 \mathrm{~mm}$ (Nippon Electric Glass Company Ltd, Otsu, Japan). Bulk grafts were fashioned from femoral head allograft (11 hips; $26 \%$ ), autografts from the patients' contralateral femoral head $(2 ; 5 \%)$, or A-W glass ceramic blocks, $2 \mathrm{~cm} \times 4 \mathrm{~cm} \times$ $1 \mathrm{~cm} \mathrm{(4;9 \% ).} \mathrm{The} \mathrm{mean} \mathrm{period} \mathrm{of} \mathrm{follow-up} \mathrm{for} \mathrm{patients}$ receiving morsellised grafts and bulk grafts was 106.9 (60 to 135 ) and 98.9 months (52 to 143), respectively. The difference was not significant $(p=0.19)$. The mean age at operation for those with morsellised grafts and bulk grafts was 61.9 (37 to 85 ) and 57.6 years (40 to 69), respectively. The difference was not significant $(\mathrm{p}=0.13)$.

Since 1997, femoral head allografts were available which had been harvested under sterile conditions and stored at $-80^{\circ} \mathrm{C}$. No bone was irradiated and no additional sterilisation procedure was undertaken. After removing the remaining cartilage and soft tissue, the femoral head was cut using an oscillating saw into an appropriate shape and size when used for the bulk allograft.

Both components were revised in all hips through a direct lateral approach with or without a sliding osteotomy of the greater trochanter. Reconstruction of the defect usually begun with restoration of the acetabular roof. Before 1997, this superior bone defect had always been filled with morsellised bone graft regardless of the stage of the defect. When the contralateral femoral head was available or the defect was large enough for a glass ceramic block, the bulk grafts were used to fill the acetabular defect. After 1997, when frozen femoral head allografts became available, the defect was filled with a structural allograft. At least two screws passed through the support ring and graft before engaging the host bone. Finally, remaining graft material was packed into the cavitary defects of the pubis and the ischium, and into the gaps between the bulk allograft and the host bone. The polyethylene component was then cemented into the metal device.

The femoral stems were made of titanium alloy (Kyocera, Kyoto, Japan) to which alumina ceramic (Kyocera) femoral heads were applied in 33 hips and zirconia ceramic (Kyocera) in nine. All the femoral heads measured 22.22 $\mathrm{mm}$. All components were cemented with CMW1 bone cement (DePuy, Blackpool, United Kingdom) for acetabular fixation and CMW3 bone cement (DePuy) for the femoral stem using third-generation cementing techniques.

Post-operative management included partial weightbearing between parallel bars or on a walking frame usually starting three days after surgery. Over two to three weeks the patient progressed to full weight-bearing. The function of the hip was evaluated using the Japanese Orthopaedic Association (JOA) hip score, which allocates 40 points for pain, 20 points for range of movement, 20 points for walking ability and 20 points for the activities of daily living, with a maximum total score of 100 points. ${ }^{18}$

The post-operative and final follow-up radiographs were compared to assess migration of the implant. The following three parameters were measured: 1) the angle of inclination of the acetabular device; 2) the horizontal migration, defined as the distance between a perpendicular reference line drawn through the teardrop and the centre of the femoral head; and 3) the vertical migration, defined as the distance between the interteardrop reference line and the centre of the femoral head. Substantial migration was defined as a change in the angle of inclination of more than $3^{\circ}$ or migration of more than $3 \mathrm{~mm} \cdot{ }^{13,19}$ Radiological failure was defined by any of three criteria: 1) substantial migration; 2) the presence of a progressive radiolucent line exceeding $2 \mathrm{~mm}$ in width in all three zones as defined by DeLee and Charnley; ${ }^{20}$ and 3 ) breakage of the screws or the device without migration or change in inclination.

Statistical analysis. We used the Kaplan-Meier productlimit method to estimate the cumulative probabilities of failure. The survivorship curves for various subgroups were compared by the log-rank test. The pre-operative and final follow-up JOA scores and the ratio of the stages of acetabular bone defect were compared using Student's $t$ test. The failure rates were compared between morsellised grafts and bulk grafts using Fisher's exact probability test. A p-value $\leq 0.05$ was considered to be significant.

\section{Results}

The JOA hip score at the last follow-up had increased from a mean pre-operative score of 48.3 (24 to 89 ) to a mean of $77.3(65$ to 95$)(p<0.01)$.

Further revision was required in two hips $(5 \%)$ because of recurrent infection in one patient and recurrent dislocation in the other. The patient with infection was a 55-yearold man with haemophilia who had undergone revision for infection 8.6 years after an earlier revision for infection. The other patient was a 58-year-old woman who had recurrent dislocation after a previous isolated revision of the femoral stem for peri-prosthetic fracture seven years after a primary THR. Both of these patients had loosening of the support ring before further revision.

Nine hips $(21 \%)$ developed fracture of the device and/ or a screw. In one $(2 \%)$ the device itself fractured, in six $(14 \%)$ the screws fractured, and in two $(5 \%)$ both the device and the screws fractured. Of these nine hips, four 
Table II. Stability of the acetabular component according to the stages of bone defect and types of graft

\begin{tabular}{|c|c|c|c|c|c|}
\hline \multirow[b]{2}{*}{ Stage } & \multicolumn{2}{|c|}{ Morsellised graft } & \multicolumn{2}{|c|}{ Bulk graft } & \multirow[b]{2}{*}{ Total } \\
\hline & Stable & Failure & Stable & Failure & \\
\hline 1 & 9 & 2 & 2 & 0 & 13 \\
\hline 2 & 5 & 4 & 5 & 0 & 14 \\
\hline 3 & 0 & 4 & 5 & 3 & 12 \\
\hline 4 & 0 & 1 & 2 & 0 & 3 \\
\hline Total & 14 & 11 & 14 & 3 & 42 \\
\hline
\end{tabular}

showed loosening, one underwent further revision surgery, and the remaining four showed no progressive radiolucency and no migration. All, however, were considered to be radiological failures. The mean period from revision surgery to fracture of a screw was 40 months (12 to $60)$ and to fracture of the device, 48 months (24 to 84$)$.

The mean change in the angle of inclination was $1.4^{\circ}$ $\left(0^{\circ}\right.$ to $\left.5^{\circ}\right)$. Four hips $(9 \%)$ showed change of more than $3^{\circ}$ in the inclination angle. The mean horizontal migration was $1.4 \mathrm{~mm}$ (0 to 3 ). At the final evaluation, the mean vertical migration was $2.3 \mathrm{~mm}$ (0 to 9), and nine hips $(21 \%)$ had vertically migrated more than $3 \mathrm{~mm}$. Overall, 11 hips $(26 \%)$ showed substantial migration in one or two directions. Complete radiolucent lines were found around six acetabular components $(14 \%)$ and two of these patients had pre-operative diagnoses of infection. All six hips were included in the 11 hips which showed substantial migration. In the 17 patients receiving bulk grafts, the bone graft had united in all except two with migration. It was difficult to assess graft union in patients who had received morsellised grafts because the A-W glass ceramic particles were radiologically dense. In total, 14 hips $(33.3 \%)$ failed by one of the definitions, 11 of 25 hips $(44 \%)$ which had received morsellised grafts and three of $17(17.6 \%)$ with bulk grafts (Table II).

Survivorship analysis was performed using failure of the acetabular component whether revised or not, as the endpoint. The survival rate of the morsellised graft group and of the bulk graft group at ten years was 53\% (95\% confidence interval (CI) $42.5 \%$ to $63.5 \%$ ) and $82 \%(95 \% \mathrm{CI}$ $72.4 \%$ to $91.6 \%$ ), respectively (Fig. 2 ). The survival curves were not significantly different $(\mathrm{p}=0.0906)$. However, in the hips with large acetabular bone defects (stage 3 or 4), the group with morsellised grafts showed more failures than those with bulk grafts ( 5 of 5 vs 3 of 10 , respectively). The difference was significant $(\mathrm{p}=0.026)$. There were three hips with bulk graft which showed failure, two with bulk femoral allograft and one with ceramic blocks.

\section{Discussion}

The mid-term results of revision THR with the Kerboull acetabular reinforcement device were satisfactory when using bulk graft in any size of defect (Fig. 3). However, morsellised grafts were generally less satisfactory (Fig. 4).

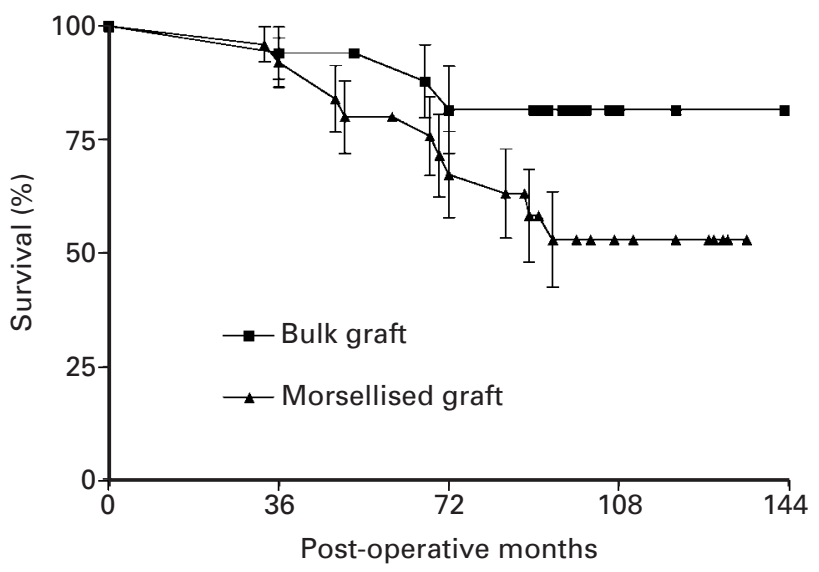

Fig. 2

Graph showing the radiological survival of the acetabular component in hips with morsellised and bulk graft. The $95 \%$ confidence intervals are shown.

The goals of revision surgery for a hip with massive loss of bone stock are to provide support for the acetabular component, to restore the normal anatomical structure, and to re-establish equality of the leg length. ${ }^{21}$ Placing the acetabular component at the correct anatomical position decreases the risk of impingement and dislocation ${ }^{21,22}$ and the joint contact force. ${ }^{20}$ Additionally, these grafts restore acetabular bone stock and benefit any future revision. However, without using reinforcement devices, revision arthroplasty using only the bulk allograft has been reported to have a higher long-term rate of failure. ${ }^{23,24}$ Kwong et $\mathrm{al}^{23}$ noted failure in $47 \%$ of cases at a mean of ten years after operation, and Shinar and Harris ${ }^{24}$ reported a rate of failure of $60 \%$ at 16 years after surgery. Garbuz et $\mathrm{al}^{21}$ recommended the use of an acetabular reinforcement ring with a bulk allograft and had an overall rate of success of $88 \%$ at a mean follow-up of 7.5 years, in contrast to a success rate of $44 \%$ in the absence of a reinforcement ring. It appears to be advisable to use a reinforcing acetabular device to protect bulk bone grafts used in load-bearing defects. ${ }^{12,13,21}$

There are a number of acetabular reinforcement devices available for revision THR, with some showing failure rates of between $14 \%$ and $24 \%$ between five and 11.4 years. ${ }^{25-31}$ Several authors reported excellent results using the Kerboull or similar acetabular reinforcement devices $(0 \%$ to $5 \%$ failure at 5.3 to 10 years). ${ }^{13,32}$ This may be a function of the device's relative flexibility allowing support for the graft without unloading it completely. During the incorporation and remodelling process, the graft bone should be partially unloaded and protected from excessive mechanical force. ${ }^{13}$

Several authorshave recommended using a reinforcement ring with a structural allograft. ${ }^{13,21,30}$ Zehntner and Ganz ${ }^{31}$ reported a failure rate of $18 \%$ using morsellised allografts with an acetabular reinforcement device at a follow-up of seven years, with $44 \%$ of devices migrating more than $2 \mathrm{~mm}$. 


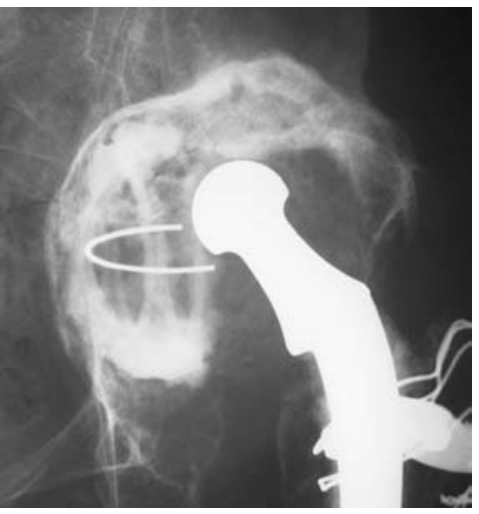

Fig. 3a

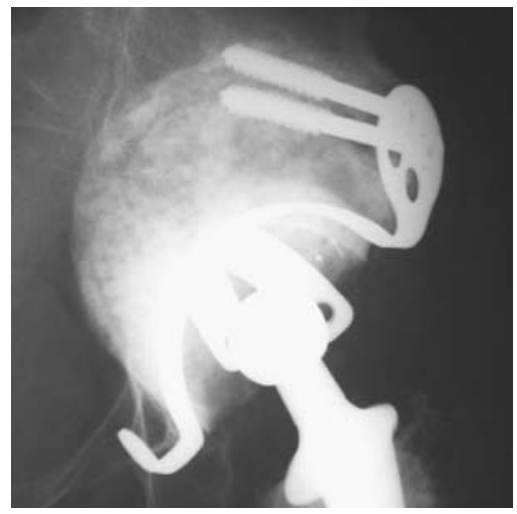

Fig. $3 b$

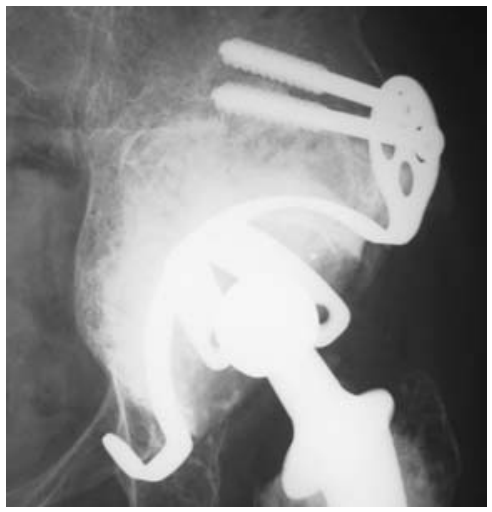

Fig. 3c

A 69-year-old woman with osteoarthritis of the hip secondary to dysplasia had revision surgery using a bulk allograft to fill a stage-4 bone defect. Radiographs a) before revision, b) one month after surgery and c) eight years after surgery with complete, bony union and remodelling and a stable acetabular component.

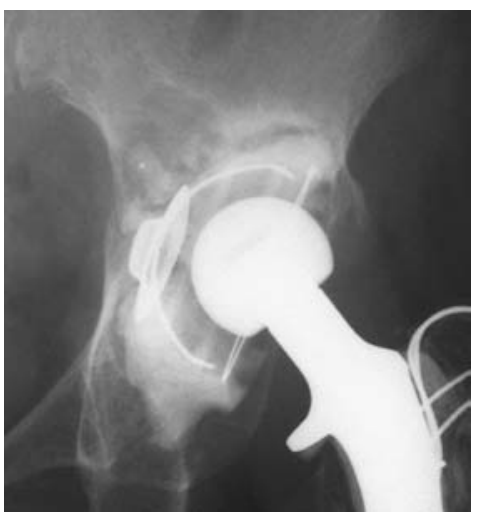

Fig. 4a

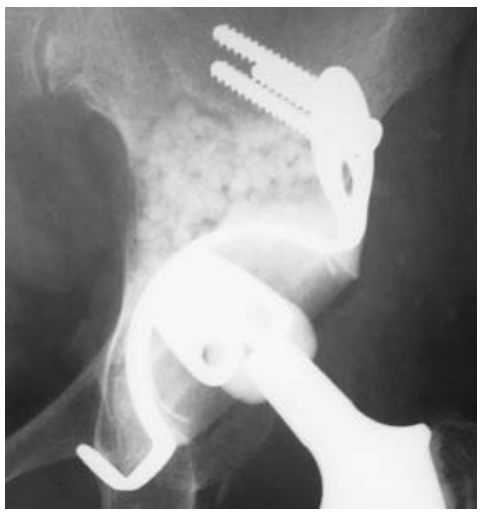

Fig. $4 b$

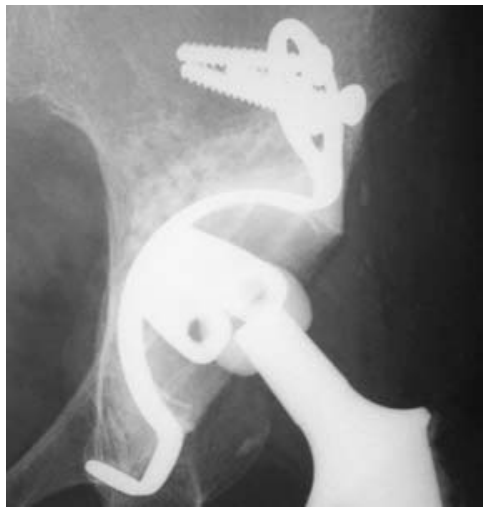

Fig. $4 \mathrm{c}$

A 58-year-old woman with osteoarthritis of the hip secondary to dysplasia had revision surgery using autogenous bone chips and A-W glass ceramic particles to fill a stage-3 bone defect. Radiographs a) before revision, b) one week after revision, c) four years after revision with vertical migration of the Kerboull device of $5 \mathrm{~mm}$ and loosening of the screws.

They suggested that cancellous allografts were incapable of supporting an acetabular component securely. Berry and Muller ${ }^{25}$ reviewed 42 failed acetabular arthroplasties reconstructed using the Burch-Schneider antiprotrusio cage and cancellous allograft. After a mean follow-up of five years, there were six failures in the 20 hips with bone grafts. The results were comparable to those which we achieved with morsellised graft.

Schreurs et al, ${ }^{8}$ using bone-impaction grafting and a cemented acetabular component, reported a survival rate with revision of the acetabular component for loosening as the end-point of $94 \%$ at ten to 17 years.

Kerboull et $\mathrm{al}^{13}$ reported better results using the Kerboull device with bulk allograft compared with our findings. In part, this may have been due to our inclusion of three hips revised for septic loosening. Additionally, four hips, with fracture of the plate or screw, but no progressive radiolucency and no migration, were classified as failures in our study.
We conclude that revision THR using the Kerboull acetabular reinforcement device in hips with a bone defect which is so large that less than half of the rounded plate of the device rests on the host bone, should be reconstructed using bulk bone graft.

We thank S. Maeno and H. Tango for their help in preparing the manuscript.

No benefits in any form have been received or will be received from a commercial party related directly or indirectly to the subject of this article.

\section{References}

1. Amstutz HC, Ma SM, Jinnah RH, Mai L. Revision of aseptic loose total hip arthroplasties. Clin Orthop 1982;170:21-3.

2. Callaghan JJ, Salvati EA, Pellicci PM, Wilson PD Jr, Ranawat CS. Results of revision for mechanical failure after cemented total hip replacement, 1979 to 1982: a two to five-year follow-up. J Bone Joint Surg [Am] 1985;67-A:1074-85.

3. Pellicci PM, Wilson PD Jr, Sledge CB, et al. Revision total hip arthroplasty. Clin Orthop 1982;170:34-41.

4. Kavanagh BF, Ilstrup DM, Fitzgerald RH. Revision total hip arthroplasty. J Bone Joint Surg [Am] 1985;67-A:517-26.

5. Hunter GA, Welsh RP, Cameron HU, Bailey WH. The results of revision of total hip arthroplasty. J Bone Joint Surg [Br] 1979;61-B:419-21. 
6. Hirst P, Esser M, Murphy JC, Hardinge K. Bone grafting for protrusio acetabuli during total hip replacement: a review of the Wrightington method in 61 hips. J Bone Joint Surg [Br] 1987;69-B:229-33

7. Mendes DG, Roffman M, Silbermann M. Reconstruction of the acetabular wall with bone graft in arthroplasty of the hip. Clin Orthop 1984;186:29-37.

8. Schreurs BM, Slooff TJJH, Gardeniers JWM, Buma P. Acetabular reconstruction with bone impaction grafting and a cemented cup: 20 years' experience. Clin Orthop 2001;393:202-15

9. Hungerford DS, Jones LC. The rationale of cementless revision of cemented arthroplasty failures. Clin Orthop 1988;235:12-24.

10. Jasty M, Harris WH. Results of total hip reconstruction using acetabular mesh in patients with acetabular deficiency. Clin Orthop 1988;237:142-9.

11. Tanzer M, Drucker D, Jasty M, McDonald M, Harris WH. Revision of the acetabular component with an uncemented Harris-Galante porous-coated prosthesis. J Bone Joint Surg [Am] 1992;74-A:987-94.

12. Gill TJ, Sledge JB, Muller ME. The management of severe acetabular bone loss using structural allograft and acetabular reinforcement devices. J Arthroplasty 2000;15:1-7.

13. Kerboull M, Hamadouche M, Kerboull L. The Kerboull acetabular reinforcement device in major acetabular reconstructions. Clin Orthop 2000;378:155-68.

14. Rosson J, Schatzker J. The use of reinforcement rings to reconstruct deficient acetabula. J Bone Joint Surg [Br] 1992;74-B:716-20.

15. van der Linde $\mathbf{M}$, Tonino $\mathbf{A}$. Acetabular revision with impacted grafting and reinforcement ring: 42 patients followed for a mean of 10 years. Acta Orthop Scand 2001:72:221-7.

16. D'Antonio JA, Capello WN, Borden LS, et al. Classification and management of acetabular abnormalities in total hip arthroplasty. Clin Orthop 1989;243:126-37.

17. Kokubo T, Shigematsu M, Nagashima Y, et al. Apatite-and wollastonite-containing glass-ceramics for prosthetic application. Bull Inst Chem Res, Kyoto Univ 1982;60:260-8.

18. Mibe J, Imakiire A, Watanabe T, Fujie T. Results of total hip arthroplasty with bone graft and support ring for protrusio acetabuli in rheumatoid arthritis. J Orthop Sci 2005; 10:8-14.

19. Peters CL, Curtain M, Samuelson KM. Acetabular revision with the Burch-Schneide antiprotrusio cage and cancellous allograft bone. J Arthroplasty 1995;10:307-12.

20. DeLee JG, Charnley J. Radiological demarcation of cemented sockets in total hip replacement. Clin Orthop 1976;121:20-32.
21. Garbuz D, Morsi E, Gross AE. Revision of the acetabular component of a total hip arthroplasty with a massive structural allograft: study with a minimum five-year follow-up. J Bone Joint Surg [Am] 1996;78-A:693-7.

22. Schutzer SE, Harris WH. High replacement of porous-coated acetabular components in complex total hip arthroplasty. J Arthroplasty 1994;9:359-67.

23. Kwong LM, Jasty M, Harris WH. High failure rate of bulk femoral head allograft in total hip acetabular reconstructions at 10 years. J Arthroplasty 1993;8:341-6.

24. Shinar AA, Harris WH. Bulk structural autogenous grafts and allografts for reconstruction of the acetabulum in total hip arthroplasty: sixteen-year-average follow-up. J Bone Joint Surg [Am] 1997;79-A:159-68.

25. Berry DJ, Muller M. Revision arthroplasty using an anti-protrusio cage for massive acetabular bone deficiencies. J Bone Joint Surg [Br] 1992;74-B:711-15.

26. Gerber A, Pisan M, Zurakowski D, Isler B. Ganz reinforcement ring for reconstruction of acetabular defects in revision total hip arthroplasty. J Bone Joint Surg [Am] 2003;85-A:2358-64.

27. Haentjens P, Boeck H, Handelberg F, Casteleyn PP, Opdecam P. Cemented acetabular reconstruction with Muller support ring: a minimum five-year clinical and roentgenographic follow-up study. Clin Orthop 1993;290:225-35.

28. Korovessis P, Stamatakis M, Baikousis A, Katonis P, Petsinis G. Muller roof reinforcement rings: medium term results. Clin Orthop 1999;362:125-37.

29. Siebenrock KA, Trochsler M, Sadri H, Ganz R. Hooked roof cup in revision of difficult loose hip prosthesis cups: results after a minimum of 10 years. Orthopade 2001;30:273-9 (in German).

30. Udomkiat P, Dorr LD, Won YY, Longjohn D, Wan Z. Technical factors for success with metal ring acetabular reconstruction. J Arthroplasty 2001;16:961-9.

31. Zehntner MK, Ganz R. Midterm results (5.5 to 10 years) of acetabular allograft reconstruction with the acetabular reinforcement ring during total hip revision. $J$ Arthroplasty 1994:9:469-79.

32. Tanaka C, Shikata J, Ikenaga M, Takahashi M. Acetabular reconstruction using a Kerboull-type acetabular reinforcement device and hydroxyapatite granules: a 3- to 8-year follow-up study. J Arthroplasty 2003;18:719-25. 